\title{
Literárnovedné myslenie v súčasnej Ukrajine
}

Філологічні семінари. Театр літературного процесу: Теорія і дійові особи. Вип. 20. Київ, 2017. 335 с. ISBN 978-617-7442-48-5.

O tom, ako a o čom rozmýšlajú literárni vedci v súčasnej Ukrajine, vela napovie aj nový, už 20. zborník prác filologického seminára, ktorý založil v Kyjevskej univerzite ešte v roku 1904 známy literárny teoretik prof. V. M. Peretc. Seminár však v 20. rokoch minulého storočia sovietsky režim zakázal, jeho účastníkov prenasledoval, ba aj niektorých fyzicky zlikvidoval. O obnovenie jeho činnosti sa postaral v roku 1996 vtedajší dekan filologickej fakulty Kyjevskej univerzity T. H. Ševčenka prof. M. K. Najenko, DrSc. Jeho iniciatívu podporili filologické pracoviská nielen Ukrajiny, ale aj Harwardskej univerzity, Varšavskej univerzity, Tbiliskej univerzity, Masarykovej univerzity, Inštitút literatúry T. H. Ševčenka AV Ukrajiny a další. Dušou a rozumom (vedeckým vedúcim) filologického seminára „Teoretické a metodologické problémy literárnej vedy“ sa stal prof. Mychajlo Najenko. Doteraz sa 20 seminárov aktívne zúčastnili významní vedci (niektorí opakovane) nielen z Ukrajiny, ale z rôznych zväzových republík bývalého ZSSR, Pol’ska, Česka, Slovenska, Nemecka, Velkej Británie, Austrálie, Kanady USA a iných. Ich číslo sa pohybuje viac ako 500 osôb, nehovoriac o pasívnych účastníkoch. Bola a je to dobrá škola pre každého literárneho vedca aj konzumenta umeleckej literatúry. Z každého seminára vzišiel vedecký zborník.

Teraz pred nami leží 20. zborník uvedeného seminára pod názvom: Divadlo literárneho procesu: teória a účinkujúce osoby, ktorý vydala Kyjivská národná univerzita T.H.Ševčenka. Autormi tohto zborníka sú vedci z Ukrajiny, Pol’ska, Česka, Velkej Británie a Slovenska, spolu 44. Predstavili pomerne širokú paletu tém, problémov, dokonca aj prístupov $\mathrm{k}$ literárnemu textu alebo literárnemu procesu vôbec. Avšak spája ich láska a úcta $\mathrm{k}$ umeleckému slovu - umeleckému literárnemu obrazu, k pokrokovým tradíciám literárnej vedy doma a vo svete. Jednotliví autori sa nekoncentrovali iba na literárny proces v Ukrajine, ale aj širšie, snažia sa posudzovat ukrajinskú literatúru a jej proces v kontexte literárneho diania v Európe, ba aj širšie. Prevažuje v ich prácach narábanie s konkrétnym literárnym textom, jeho pozorné prečítanie, formalistický, štrukturalistický prístup, ktorý má isté tradície aj v ukrajinskej literárnej vede ešte z čias jeho zakladatela prof. V. M. Peretca.

V našej krátkej úvahe nemáme možnost', aby sme uviedli názvy všetkých štúdií, tým viac nemáme možnost', aby sme ich analyzovali, poukázali na to všetko nové, čo prinášajú. Sústredíme sa iba na niektoré práce.

Už prvá štúdia prof. M. Najenka Literárny proces a jeho imitácia udala tón prácam celého zborníka. V nej autor podrobne pojednáva o teoretických historicko-literárnych 
aspektoch literárneho procesu nielen $\mathrm{v}$ Ukrajine. Literárny proces analyzuje na základe „obrazových systémov, ktoré dominovali v rozličných kultúrno-historických epochách", ${ }^{1}$ usiluje sa podat svoju vlastnú definíciu literárneho procesu, tohto živého organizmu literárneho rozvoja. Považuje, že v základe každého literárneho procesu leží „jedine forma umeleckého myslenia“. Zamýšla sa medzi iným aj nad tým, ako v súčasnej ukrajinskej literatúre prichádza namiesto postmodernizmu „nový historizmus alebo metamodernizmus “ ${ }^{3}$ tvrdí, že postmodernizmus v každej krajine má, či mal hlboko národný (nacionálny) charakter a obsah, uvádza, kedy existoval či existuje skutočný literárny proces a kedy iba jeho imitácia, pritom uvádza rád diel, ktoré to dokazujú.

Hned po ňom nasleduje štúdia prof. I. Pospíšila Hra v literatúre literatúrou a s literatúrou (Nie je to jeho prvá štúdia uverejnená $\mathrm{v}$ zborníkoch filologického seminára. Je to už piata či šiesta a vždy originálna, podnetná), v ktorej sa okrem iného zaoberá vážnou problematikou literárneho procesu a síce udelovaním literárnych cien v rôznych štátoch, vrátane udelovania Nobelovej ceny za literatúru, ktoré považuje za súčast' hry v literatúre a s literatúrou na „pozadí ekonomických, ideologických, politických záujmov“. ${ }^{4}$ Prichádza k záveru, že aj tu jestvuje korupcia, známosti, ked namiesto skutočných estetických hodnôt, sa navrhujú a oceňujú často rôzne mimoliterárne, ideologické, politické „hodnoty“ a záujmy biznisu. Nediví sa, že taká „prax“ často privádza literatúru v súčasnom svete do „osobitného druhu šou-biznisu“. Súčasne poukazuje aj na problematiku identickosti národných literatúr, čo sa prejavuje tiež v svojráznej hre, spojenej s revíziou predchádzajúcich prístupov k literatúre. Názor prof. I. Pospíšila o šou-literatúre nechtiac a nezávisle rozvíja prof. E. Šestopalovová v štúdii Reálna šou - prečiarknutý text umeleckej literatúry. Hra v umeleckom diele zaujala aj prof. O. Koliňkovú, čo aj dokázala v svojej štúdii Hra ako dominanta umeleckého štýlu Mily Ivancovej. Poukazuje, aké miesto, funkciu zaujíma hra v rozličných komponentoch umeleckej štruktúry jej diel, pri tvorbe postáv, v akcentácií ideových aspektov vo vzt’ahu k životu a pod. Vidíme, že otázka hry v umeleckej literatúre stále častejšie zaujíma nielen spisovatelov, ale aj literárnych vedcov Ukrajiny.

Prof. N.Šlachovová v práci Čítanie ako literárnovedný fenomén sa zaoberá problematikou komunikatívno-receptívneho prístupu k literatúre ako k umeniu slova. Svojím spôsobom jej niektoré myšlienky rozvíja prof. H. Kloček v štúdii Otvorené dielo a problém mnohých spôsobov jeho interpretácie, v ktorej dokazuje, že problém

1 Fìlolohični seminary. Teatr literaturnoho procesu: Teorìja i dijovì osoby. Vyp. 20. Kyjiv, 2017, s. 9.

2 Tamže, s. 11.

3 Tamže, s. 14.

4 Tamže, s. 19. 
rozboru a hodnotenia umeleckého diela, je aktuálny najmä pre diela s tzv. otvoreným koncom. Svoje teoretické názory aplikuje na poézii M.Vinhranovského. Ďalej tento problém rozvíja prof. O. Bystrovová v štúdii Titulná strana a ilustrácie literárneho diela ako receptívny faktor, ked podrobila rozboru funkcie titulnej strany diela v porovnaní s funkciami divadelného plagátu. Problém hodnotenia, čítania a predaja literatúry vôbec zaujal prof. A. Tkačenka, o čom svedčí jeho práca Romány masovej kultúry očami študentov-literátov. Kedže jestvujú rôzne kritériá hodnotenia textov masovej kultúry, ktoré panujú v Ukrajine, autor navrhol „integrovaný prístup, ktorý berie do úvahy nielen tradičné nároky na obsah a formu diela, ale aj pragmatické záujmy vydavatelov a požiadavky čitatelov". Myslí si, že tak pomôže posilnit umelecko-estetické hodnoty a čítanie románov nielen masovej kultúry. ${ }^{5}$

V zborníku nachádzame celý rád štúdií venovaných rozboru a hodnoteniu jednotlivých diel či tvorby toho alebo iného autora od najstarších čias po súčasnost'. Ich zoznam je pomerne velký. My sa zastavíme iba pri dvoch-troch. Najprv chceme upozornit, že ukrajinskí literárni vedci sa aj nadalej zaujímajú o českú literatúru. Svedčí o tom štúdia O.Palij Umelecká reflexia vojny $v$ českej próze 6o-ch rokov XX st., v ktorej sa zaoberá, ako J. Škvorecký, B. Hrabal a L. Fuks, každý originálne, neopakovatelne, experimentálne sa zmocnil protivojnovej témy, ako a čím každý z nich zaujal osobitné miesto v kontexte českej prózy 6o. rokov 20. st. Čitatel zborníka sa dočíta aj o literárnom procese Ukrajincov východného Slovenska v práci Niektoré osobitosti rozvoja ukrajinskej literatúry Slovenska na prelome 20.-21. storočia, autorom ktorej je autor týchto riadkov. Pred ním sa zo Slovenska v zborníku filologického seminára prezentovali svojimi štúdiami J. Jurčo, N. Kyselová a S. Makara.

Osobitne ma zaujala štúdia prof. N. Bernadskej Od Kyjeva do Mukačeva, alebo ako sa zapojit do súčasného literárneho procesu, lebo sa to týka nielen tvorcov literatúry Zakarpatskej či iných oblastí Ukrajiny, ale aj ukrajinských spisovatelov východného Slovenska a vôbec Ukrajincov, píšucich po ukrajinsky, ktorí sú roztrúsení po celom svete. Na tvorbu týchto autorov mnohí kyjevskí literárni historici a kritici často zabúdajú, ignorujú a nepovažujú ich za súčast̉ literárneho procesu ukrajinskej literatúry. N. Bernadská túto tradíciu porušila, ked tvorbu zakarpatského autora D. Kešelu „zapísala“, či zaradila do súčasného literárneho procesu. S jej hodnotením jeho jednotlivých diel a tvorby vôbec súhlasím. Súhlasím s jej tvrdením, že „tajomstvo majstrovstva talentovaného autora (D. Kešelu - M. R.) spočíva v jeho unikátnosti, lebo v súčasnej ukrajinskej literatúre prozaici vedia pracovat’ s charakterovými postavami, demonštrovat’ svoju erudíciu, ktorá sa prejavuje v intertexte, budovat zaujímavé sujety, hrajúc sa pritom s čitatelom, ale nie vždy vedia rozosmiat čitatela. Práve smiech D. Kešela vrátil do romanistiky, smiech zemitý, inokedy aj hrubý svojim naturalizmom, 
ale smiech očistujúci, svetlý, život utvrdzujúci“. ${ }^{6}$ Tvorbu Dmytra Kešelu poznajú aj na Slovensku, hoci nie do takej miery, ako by si zaslúžila.

Vedomý som si toho, že ani zdaleka sa mi nepodarilo upozornit na to velké množstvo poznatkov, impulzov, ktoré prinášajú další jednotliví autori. Napriek tomu sa nazdávame, že aj z týchto riadkov môžeme si vytvorit určitý obraz o literárnom myslení v Ukrajine. Teší nás, že vedenie filologického seminára a redakčnej rady zborníka sú otvorení pre rozličné, dokonca aj protikladné názory na literatúru, čím umožňujú hladat najobjektívnejšie, najmodernejšie spôsoby a metódy hodnotenia umeleckej literatúry a jej procesu.

Michal Roman

\section{Literatúra:}

Fïlolohičnì seminary. Teatr literaturnoho procesu: Teorija ì dijovì osoby. Vyp. 20. Kyjiv, 2017. 335 s. ISBN 978-617-7442-48-5. 